\title{
NEUTRONIC ANALYSIS ON IRRADIATION OF THE LEU ELECTROPLATING TARGET IN THE RSG-GAS REACTOR FOR PRODUCTION OF ${ }^{99 M O}$ RADIONUCLIDE
}

\section{ANALISIS NEUTRONIK PADA IRADIASI TARGET LEU ELEKTROPLATING DALAM REAKTOR RSG-GAS UNTUK PRODUKSI RADIONUKLIDA ${ }^{99} \mathrm{MO}$}

\author{
Surian Pinem 1 , Tagor Malem Sembiring², Tukiran'1, Iman Kuntoro ${ }^{1}$ \\ ${ }^{1}$ Center for Nuclear Reactor Technology and Safety, National Nuclear Energy Agency (BATAN), Kawasan \\ Puspipitek Serpong Gd. No. 80, Tangerang Selatan, Indonesia (15310) \\ ${ }^{2}$ Center for Nuclear Energy System Assessment, National Nuclear Energy Agency (BATAN), Jl. Kuningan \\ Barat, Mampang Prapatan, Jakarta, Indonesia (12710edua \\ E-mail:pinem@batan.go.id
}

Received 28 May 2018, received in revised form 26 July 2018, accepted 15 August 2018

\begin{abstract}
ABSTRAK
Neutronic analysis on irradiation of the LEU electroplating target in the RSG-GAS reactor for production of ${ }^{99} \mathrm{Mo}$ radionuclide. RSG-GAS reactor is a research reactor operated for radioisotope production, neutron activation analysis, research material testing, industry demand, $R \& D$ institutions and universities. The irradiation of the LEU target on the reactor core to produce ${ }^{99} \mathrm{Mo}$ radioisotope is one of the routine activities of RSG-GAS reactor operation. The target insertion in the core will change the neutronic characteristic of the core so it can exceed the safety limits of reactor operation. The neutronic parameters due to the insertion of the LEU electroplating target into the reactor core irradiation facility is analyzed in this paper. The neutronic parameters for optimizing the LEU electroplating irradiated target are important for the safety of the reactor operation. Neutronic parameter calculations were performed using WIMS/D5 and Batan3DIFF codes routinely used for RSG-GAS core calculations. Based on calculations irradiating the LEU electroplating target in a CIP irradiation position of $36 \mathrm{~g}$ causes a reactivity change of $597.724 \mathrm{pcm}$ and a maximum radial power peaking factor of 1.3078. The values are within the limits permitted for the safety of the reactor operation i.e. the maximum reactivity change and radial power peaking factor of $2000 \mathrm{pcm}$ and 1.4, respectively.
\end{abstract}

Keywords:LEU, radioisotope ${ }^{99}$ Mo, neutronic parameters, RSG-GAS reactor

\begin{abstract}
Analisis neutronik pada iradiasi target LEU elektroplating dalam reaktor RSG-GAS untuk produksi radionuklida ${ }^{99}$ Mo.Reaktor RSG-GAS adalah reaktor riset yang dioperasikan untuk keperluan produksi radioisotop, analisis aktivasi neutron, penelitian, uji material, permintaan dari industri, lembaga litbang dan universitas. Iradiasi target LEU pada teras reaktor untuk menghasilkan radioisotop ${ }^{99} \mathrm{Mo}$ adalah salah satu kegiatan rutin operasi reaktor RSG-GAS. Masuknya target kedalam teras akan mengubah karakteristik teras sehingga dapat mengganggu keselamatan operasi reaktor. Parameter neutronik akibat iradiasi LEU electroplating target pada fasilitas iradiasi teras reaktor dianalisis dalam makalah ini. Parameter neutronik untuk optimalisasi iradiasi target LEU penting untuk keselamatan operasi reaktor. Perhitungan parameter neutronic dilakukan menggunakan WIMS/D5 dan Batan-3DIFF code yang secara rutin digunakan untuk perhitungan teras RSG-GAS. Berdasarkan hasil perhitungan dengan mengiradiasi LEU electroplating target dalam posisi iradiasi CIP sebanyak $36 \mathrm{~g}$ menyebabkan perubahan reaktivitas sebesar $597.724 \mathrm{pcm}$ dan radial power peaking factor maksimum sebesar 1.3078. Besaran tersebut keduanya masih berada dalam batas yang diizinkan untuk keselamatan operasi reaktor yaitu masing-masing perubahan reaktivitas dan factor puncak daya maksimum adalah 2000 pcm dan 1.4 .
\end{abstract}

Kata kunci:LEU, radioisotop ${ }^{99} \mathrm{Mo}$, parameter neutronik, reaktor RSG-GAS

\section{INTRODUCTION}

DSG-GAS (Reaktor Serba Guna-G.A. Siwabessy) is a multi-purpose reactor based on the open pool MTR R(Material Testing Reactor) type reactor. The reactor is operated for the research and development of nuclear science and technology as well as for beam tube applications and radioisotope (RI) production. It uses the low enrichment uranium $\left(\sim 19.75 \mathrm{w} / 0{ }^{235} \mathrm{U}\right)$ of silicide fuel $\left(\mathrm{U}_{3} \mathrm{Si}_{2}-\mathrm{Al}\right)$ with a uranium density of $2.96 \mathrm{~g} / \mathrm{cc}$ or equivalent 
Jurnal Iptek Nuklir Ganendra

Ganendra Journal of Nuclear Science and Technology

Vol. 21 No. 2, July $2018: 55-61$

to $250 \mathrm{~g}$ of $235 \mathrm{U}$ in the standard fuel element. The RSG-GAS reactor has an average thermal neutron flux of $2 \times$ $10^{14} \mathrm{n} / \mathrm{cm}^{2} \mathrm{~s}$ at $30 \mathrm{MW}$ of power in eight central in-core grid positions [1].

The radioisotope targets, such as $\mathrm{TeO}_{2}$, Iridium, $\mathrm{Gd}_{2} \mathrm{O}_{3}$, Tungsten-188, $\mathrm{WO}_{3}, \mathrm{Sm}_{2} \mathrm{O}_{3}, \mathrm{MoO}_{3}$ and LEU electroplating, are irradiated in the RSG-GAS reactor, regularly. The LEU electroplating target is main RI target for production ${ }^{99} \mathrm{Mo}$ radionuclide in the core. All targets are irradiated in the 4 Irradiation Position Centers (CIP) and 4 Irradiation Position (IP) due to the height the thermal neutron flux.

Studies in optimizing the irradiation target in the research reactor have been carried out, so the reactor operation to be more economic [2-4]. For RSG-GAS reactor, the similar studies have been carried out, further, specifically to the single or multi targets $[5,6]$. All studies are focused on the ${ }^{99} \mathrm{Mo}$ radionuclide production since there are many request form the local or domestic market. The ${ }^{99} \mathrm{Mo}$ radionuclide is produced with transmutation of ${ }^{98} \mathrm{Mo}$ to ${ }^{99} \mathrm{Mo}$ by the neutron absorption or uranium-235 fission $\left({ }^{235} \mathrm{U}\right)$ by neutron absorption[7,8]. In recent years, there has been a radioisotope crisis for health, especially ${ }^{99 M o} / 99 \mathrm{mTc}$, which is used about $80 \%$ for nuclear diagnostics for 30 million people every year worldwide $[9,10]$. Those facts inspired us to examine more about the optimum production of the ${ }^{99} \mathrm{Mo}$ radionuclide in RSG-GAS reactor. The intention of this research work is to determine the capacity of RSG-GAS reactor in the production of the ${ }^{99}$ Mo radionuclide based on the LEU electroplating technology.

The study on the optimum LEU electroplating target has been carried out in Ref. [6]. However, the LEU target is combined with the gemstone target that inserted in the IPs core grid position. All calculations are carried out by the 2-dimension multigroup neutron diffusion method code, BATAN-2DIFF [11]. When the local market demand increasing, we assumed that all in-core grid positions, 4 IPs and 4 CIPs, should be used for the LEU electroplating target irradiation. The active length of LEU electroplating target $(40 \mathrm{~cm})$ is not the same as the core active length $(60 \mathrm{~cm})$. Therefore, in this study, an optimization study for the single target of LEU electroplating in the CIPs positions by using 3-dimension multigroup neutron diffusion method code, BATAN-3DIFF is implemented [11].

The important core parameters that should be calculated in this study are reactivity changes, power peaking factor and thermal neutron flux as the determination of target activity $[12,13]$. The safety limit, such as minimum stuck rod margin, should be maintained for the optimum target. All neutron cross-sections for LEU electrolating are generated by neutron transport code of WIMS/D5 code [14]. The Batan-3DIFF code was developed by BATAN and has been validated using RSG-GAS first core data and is routinely used in RSG-GAS reactor operations. The results of this research work can be used for the next step safety analysis such as thermal-hydraulic and transient analysis [15].

\section{METHODOLOGY}

\section{Brief Description of LEU Electroplating Target}

Table 1 shows the dimension and composition of LEU elctroplating target that used for RSG-GAS core. The target is SS-304L cylindrical capsule with the active height (fuel zone) of $40 \mathrm{~cm}$. The target is inserted in the a hole of stringer. Since one stringer has 3 holes, it means that 3 target capsules can be loaded into 1 core grid position.

RSG-GAS reactor has 8 in-core grid positions, 4 CIP (D-6, D-7, E-6 and E-7) and IP (B-6, D-9, E-4 and G 7). It is showed that the maximum number of stringer holes in the core is 24 . Figure 1 shows the RSG-GAS core configuration with the in-core grid positions.

Table 1. Dimension and composition of LEU electroplating target and stringer [5]

\begin{tabular}{lll}
\hline Zone & Height, cm & Composition \\
\hline I & 12 & Stringer $\left(\mathrm{H}_{2} \mathrm{O}+\mathrm{All}\right)$ \\
II & 2.51 & Stringer $\left(\left(\mathrm{H}_{2} \mathrm{O}+\mathrm{Al}\right)\right.$ and lid $(\mathrm{SS}-304 \mathrm{~L}+\mathrm{H} 2 \mathrm{O})$ \\
III & 2.745 & Stringer $\left((\mathrm{H} 2 \mathrm{O}+\mathrm{Al})+\right.$ top part $\left(\mathrm{SS}-304 \mathrm{~L}+\mathrm{He}+\mathrm{H}_{2} \mathrm{O}\right)$ \\
IV & 40 & Stringer $\left(\left(\mathrm{H}_{2} \mathrm{O}+\mathrm{Al}\right)+\right.$ active part $\left(\mathrm{SS}-304 \mathrm{~L}+\mathrm{LEU}+\mathrm{He}+\mathrm{H}_{2} \mathrm{O}\right)$ \\
V & 2.745 & Stringer $\left(\left(\mathrm{H}_{2} \mathrm{O}+\mathrm{Al}\right)+\right.$ bottome part $\left(\mathrm{SS}-304 \mathrm{~L}+\mathrm{He}+\mathrm{H}_{2} \mathrm{O}\right)$ \\
\hline
\end{tabular}




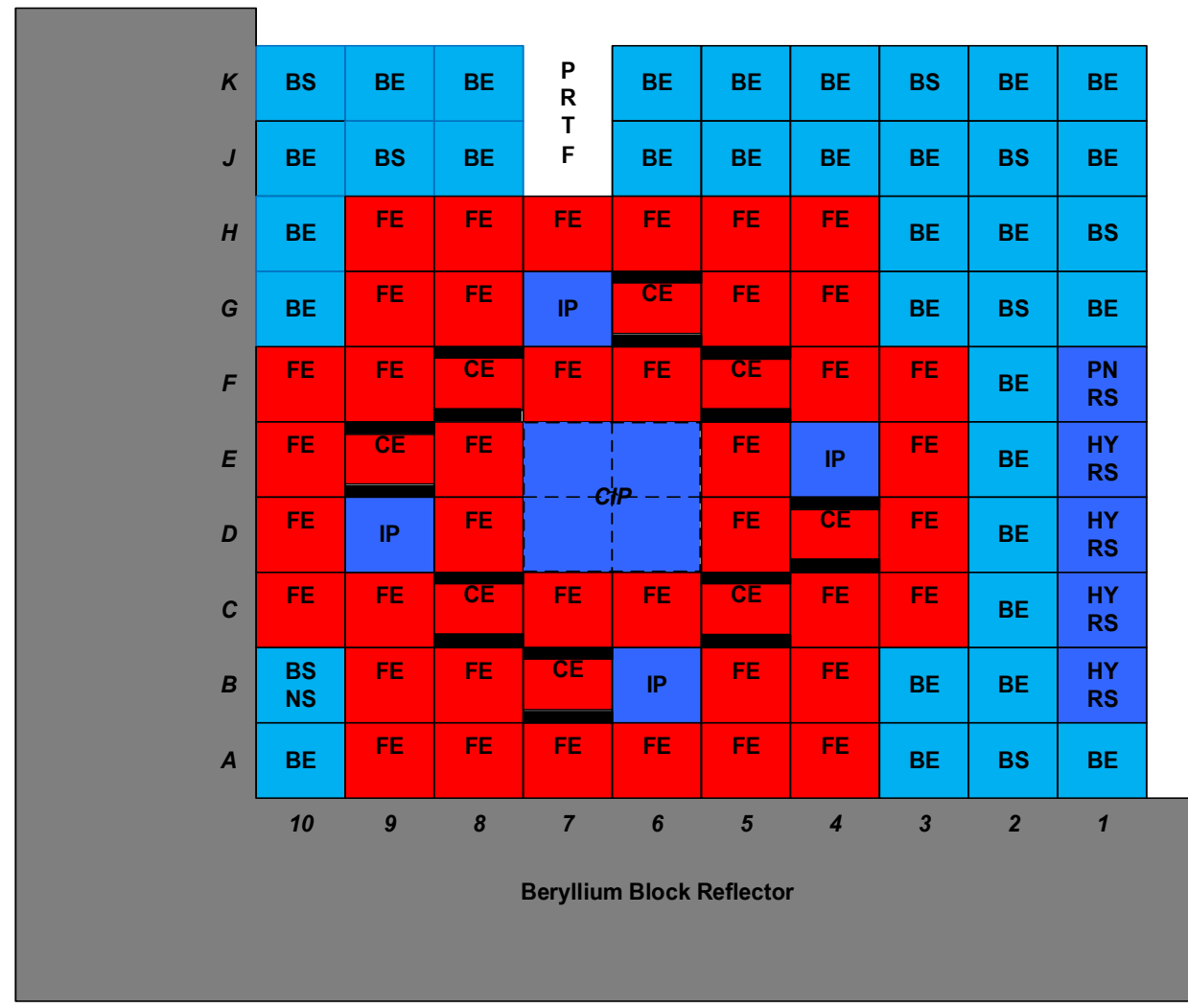

Note $: \mathrm{FE}=$ Fuel Element, $\mathrm{CE}=$ Control Element, $\mathrm{BE}=\mathrm{Be}$ Reflector Element, $\mathrm{BS}=\mathrm{Be}$ Reflector Element With Plug, IP = Iradiation Position, CIP = Central Iradiation Position, PNRS = Pneumatic Rabbit System, HYRS = Hydraulic Rabbit System

Fig. 1. Equilibrium silicide core of RSG-GAS reactor

\section{Cell and Core Calculations}

Cell calculation were carried out by the WIMS/D5 code for the generation of the fuel and control fuel elements and core materials. The code will generate 4 energy group constants, i.e. D, diffusion coefficient, $\Sigma a$, absorption macroscopic cross-section, and $v \Sigma f$, fission production macroscopic cross section. All homogenizedgroup constants are used in the core calculations by using the Batan-3DIFF code. The RSG-GAS core is modeled into 3-dimension core geometry of $X-Y-Z$. The neutron cross section for all zones in the Table 1 are generated by WIMSD/5 code.

The core calculations are carried out for:

- Excess reactivity change for with and without target, \% $\Delta \mathrm{k} / \mathrm{k}$

- Radial power peaking factor

- Axial power peaking factor as a function of control rod insertion

- The power peaking factor at the target

Although the target mass is relatively small compared to the uranium mass, it can give a strong effect if the macroscopic cross-section of the neutron absorption is large. Since the capsule are modeled in 3-deminsional, axially, it is expected the calculated result is better than 2-dimensional calculations [6].

Optimization is done by insertion of the LEU target into 4 core grid positions of CIPs. By the safety limit of reactor operation, there is no an explicit limit value of the positive reactivity change, instead for the total negative reactivity is $2 \% \Delta \mathrm{k} / \mathrm{k}$. Therefore, in this paper, it is chosen that the maximum positive reactivity changes for the CIPs is $0.5 \% \Delta \mathrm{k} / \mathrm{k}$. In addition to the change in reactivity, the power peaking factors are calculated because those are very important for the safety of reactor operation [16]. The calculation diagram of neutronic parameters due to irradiation of LEU target into the core is shown in Figure 2. 


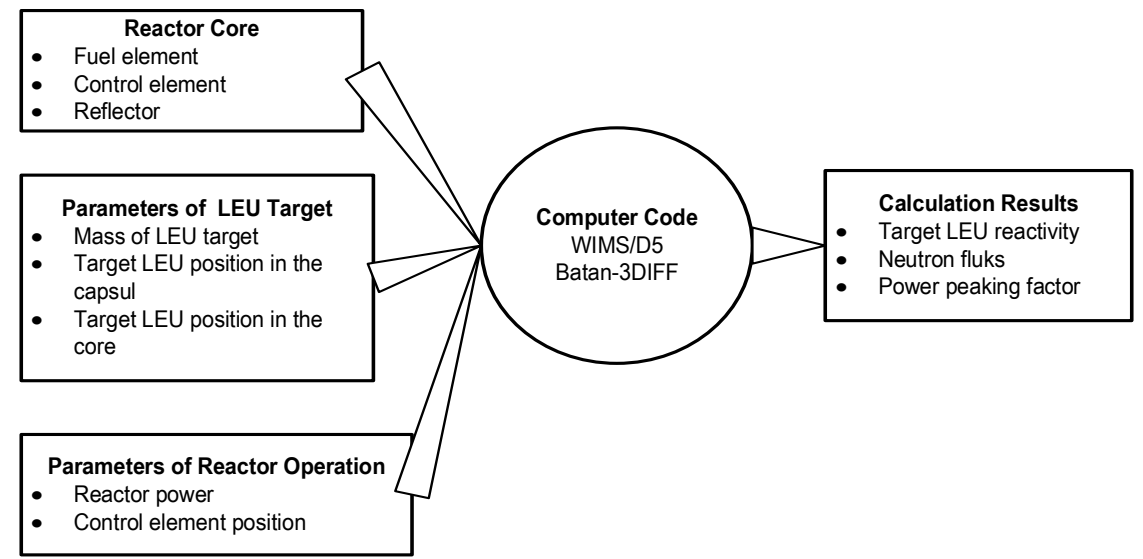

Fig. 2. Neutronic parameter calculation flow-chart for LEU target inserted to the core

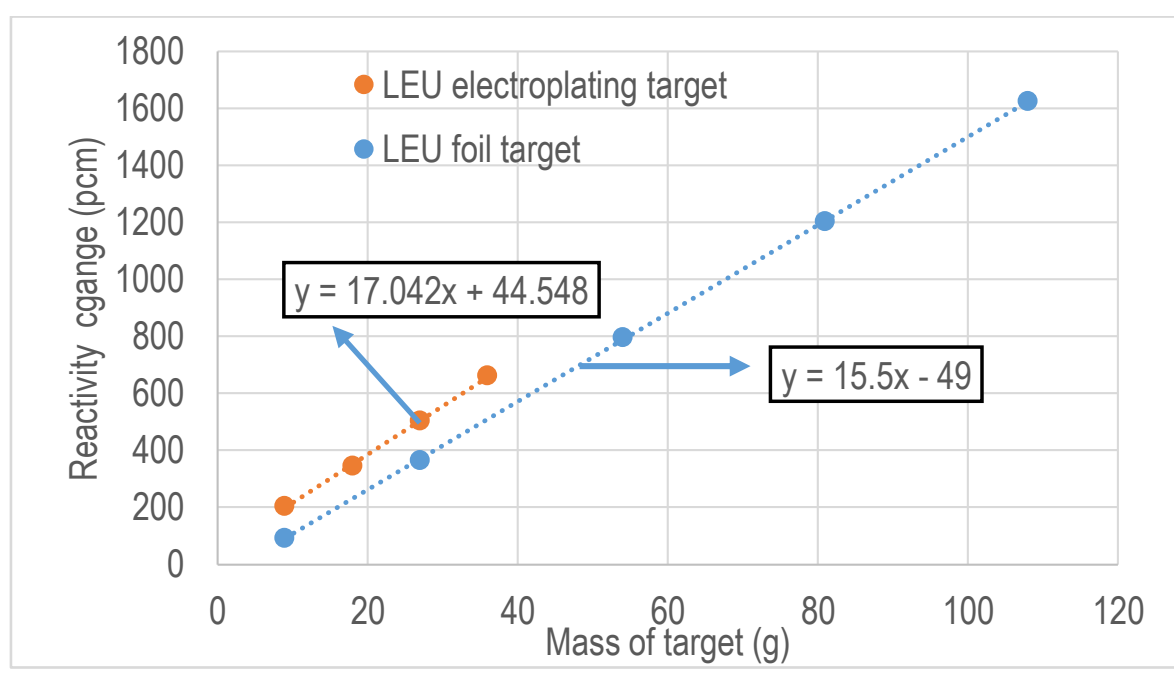

Fig. 3. Reactivity change as a function of the number of irradiation target inserted into the core

\section{RESULTS AND DISCUSSION}

The calculation of neutronic parameters with the insertion of LEU electroplating targets into the core is done with several possible number and target positions in the core. The result of calculation with the target LEU irradiation at the CIP position is shown in Table 2. The maximum number of target LEU electroplating in the CIP position is $36 \mathrm{~g}$. Reactivity change due to target irradiation is $597.724 \mathrm{pcm}$. This result is still below the specified limit of $2000 \mathrm{pcm}$. Compared with target LEU foil [6], the number of irradiated targets in CIP was $108 \mathrm{~g}$ with reactivity change of $1179.545 \mathrm{pcm}$.

The maximum number of LEU targets into the core can be determined by using result in Figure 3. Based on Figure 3, the target number and reactivity changes are linear. Based on the linear equations in Figure. 3 then the maximum amount of LEU electroplating that can be irradiated in reactor core is $114 \mathrm{~g}$ andwith irradiated LEU foil at $132 \mathrm{~g}$. It means that, for 8 positions $72 \mathrm{~g}$ can be produced for LEU electroplating while $132 \mathrm{~g}$ for LEU foil at 5 irradiation facility positions. If case of the irradiated target is less than LEU electroplating, the LEU foil is better than LEU electroplating due to easier handling management. If irradiation facility (IP) is used for irradiation of topaz stones and needs a lot of target irradiation then LEU foil will be more optimal.

Table 2. Reactivity changes when LEU target are irradiated on CIP

\begin{tabular}{llllll}
\hline No. & Irradiation posisition & Type target & Total mass $(\mathrm{g})$ & keff $(\% \Delta \mathrm{k} / \mathrm{k})$ & Reactivity change $(\mathrm{pcm})$ \\
\hline $\mathbf{1}$ & No target & - & - & 1.100629091 & - \\
$\mathbf{2}$ & CIP (E-6, E-7, D-6, D-7) & Electroplating & $36 \mathrm{~g}$ & 1.107917786 & 597.724 \\
$\mathbf{3}$ & CIP (E-6, E-7, D-6, D-7) & Foil & $108 \mathrm{~g}$ & 1.115105867 & 1179.545 \\
\hline
\end{tabular}




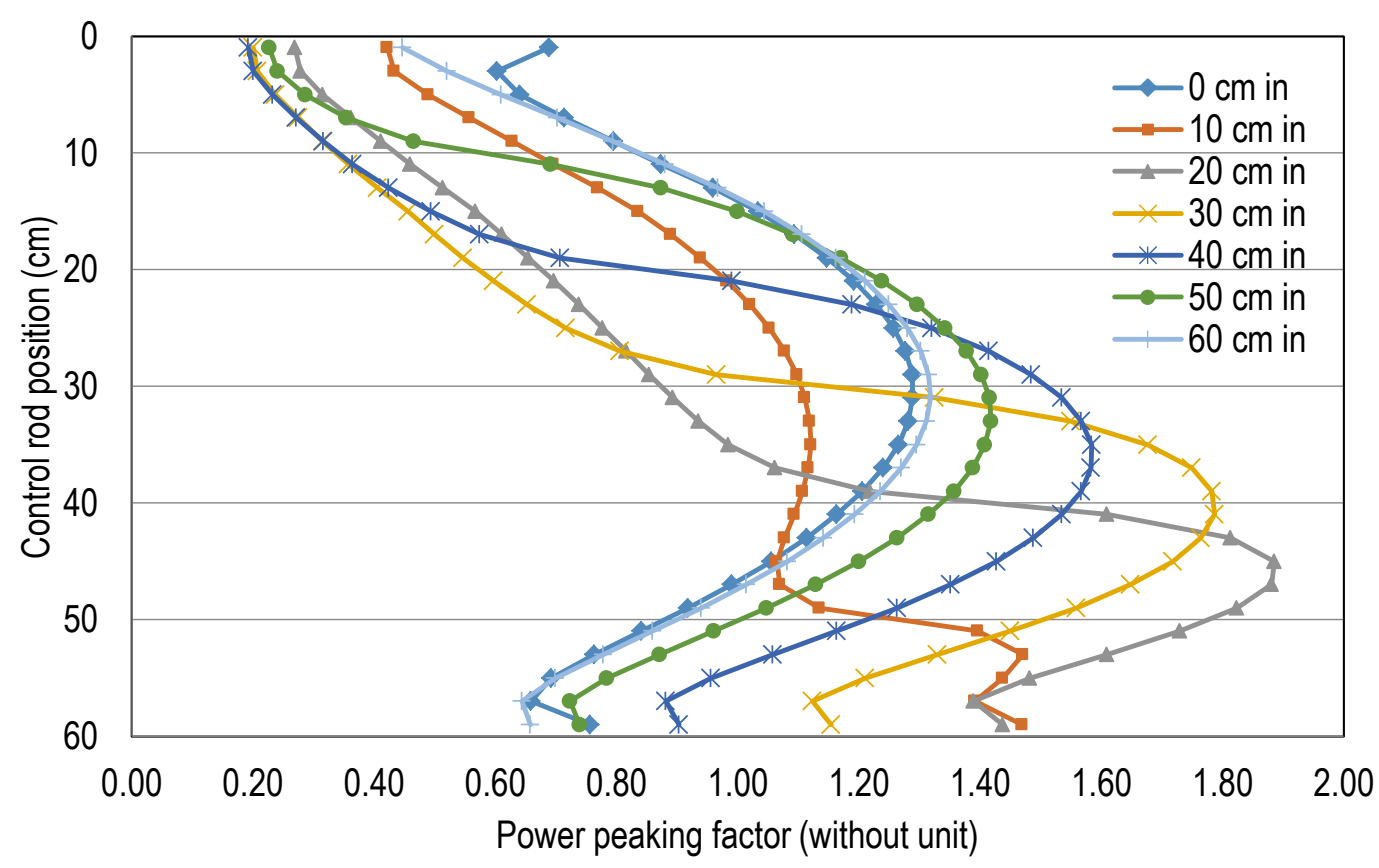

Fig. 4. Axial power peaking factor as a function of control rod position for LEU electroplating in the core

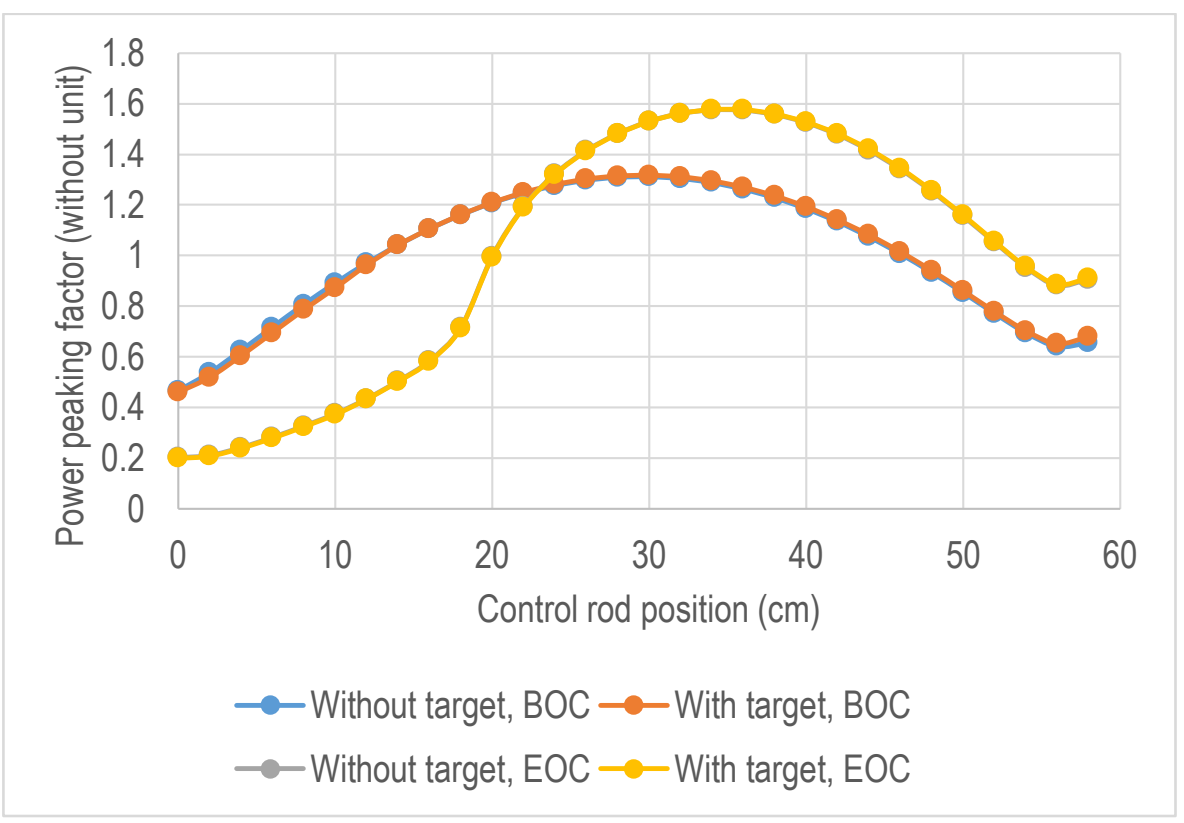

Fig. 5. The axial distribution of power peaking factor without dan with target at CIP

The distribution of axial power peaking factor (ppf) as a function of control rod position when all irradiation facilities are subjected to LEU electroplating targets is shown in Figure 4 . The value of maximum axial ppf occur when control rods are inserted $20 \mathrm{~cm}$ into the core. The value of this ppf distribution will be used for thermodynamic analysis of the core with the target inserted into the core.

Máximum valúes of radial and axial power peaking factors with irradiation of LEU electroplating at CIP for the beginning of cycle (BOC) are 1.2793 and 1.3171, and at end of cycle (EOC) are 1.3078 and 1.5835, respectively. For EOC conditions there is a rise in the value of ppf radial as well as for the axial position but still within the allowable limit of the maximum radial and axial ppf is less than 1.4 and 1.8, respectively[15]. The axial ppf distribution of the CIP on the target and with the LEU electroplating target in the core is shown in Figure 5. In Figure 5, there is no ppf change with the target inserted into the CIP irradiation position. 


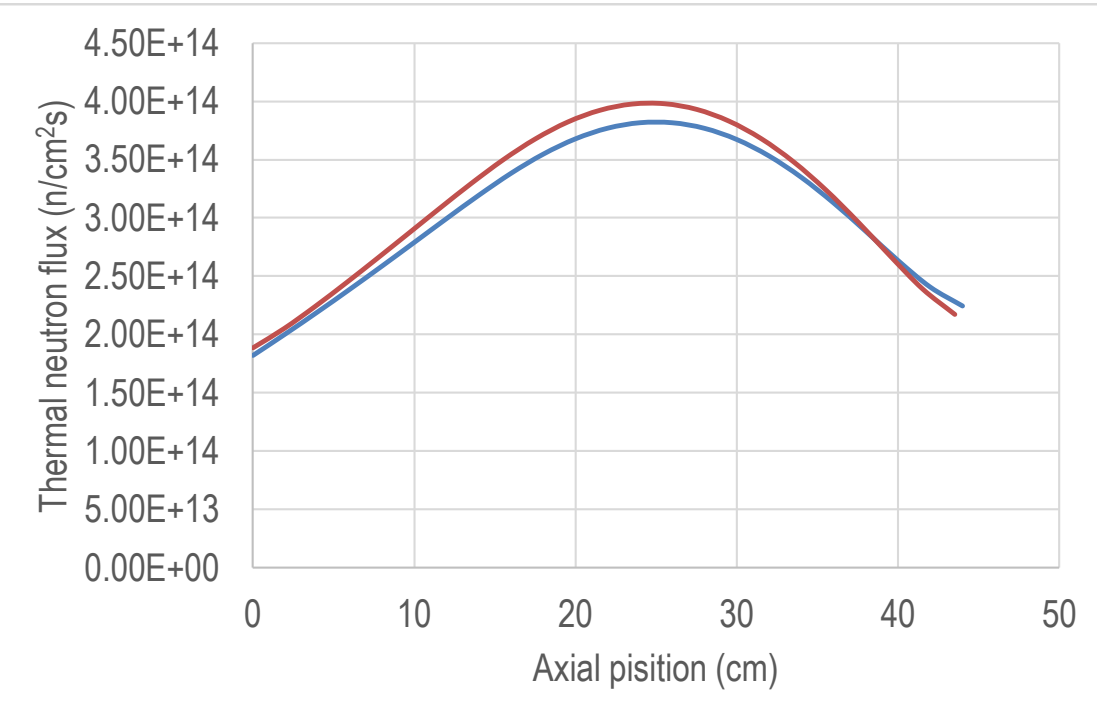

— Thermal flux without target — Thermal flux with target

Fig. 6. Axial thermal neutron flux distribution in D-6 core grid position

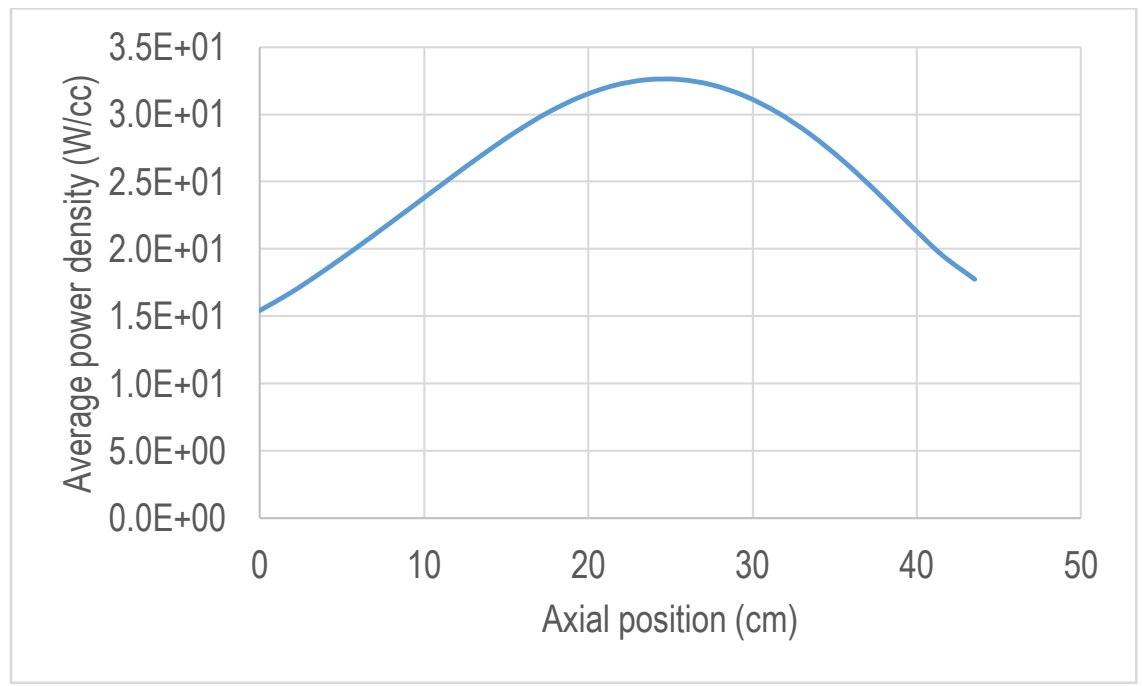

Fig. 7. The axial average power density of the LEU electroplating target in D-6 core grid position

Figure 6 shows that the axial thermal neutron flux distribution is not strongly depend on the LEU target because the mass of LEU is not so high compare with the fuel element. It is clear from Figure 7 that the maximum average power density at the target is about of $33 \mathrm{~W} / \mathrm{cc}$. It is important to be note that the target is homogenized zone. Therefore, to determine the real power value, it should be corrected by the volume fraction. Fortunately the value is far from the power density in the standard or control fuel element. The average power density in the equilibrium silicide core at rated power is $1537 \mathrm{~W} / \mathrm{cc}$ and the maximum power density $8357 \mathrm{~W} / \mathrm{cc}[17]$.

\section{CONCLUSIONS}

The optimization of LEU target at RSG-GAS core has been carried out by using Batan-3DIFF code.This research showed that the optimum target strongly depend on irradiation position of the target at the core. Target optimization can be done based on position and type of target where if radioisotope production is minimum,LEU electroplating will be more efficient than LEU foil. The results of neutronic parameter calculations when LEU electroplating targets irradiated at the CIP facility show that the safety limits of the operationare still fulfilled. 


\section{ACKNOWLEDGMENTS}

This research work was supported by Insinas Riset Pratama Individu in the years of 2018. Authors express their gratitude to the Head of PTKRN-BATAN as well as the staff of Reactor Physics and Technology Division of PTKRN-BATAN for their cooperation.

\section{REFERENCES}

[1] S. Pinem, T. M. Sembiring, and P. H. Liem, "Neutronic and Thermal-Hydraulic Safety Analysis for the Optimization of the Uranium Foil Target in the RSG-GAS Reactor," Atom Indones., vol. 42, no. 3, pp. 123-128, 2016.

[2] T. Mahmood and M. Iqbal, "Optimization study and neutronic design calculations of LEU fuelled homogeneous aqueous solution nuclear reactors for the production of short lived fission product isotopes," Ann. Nucl. Energy, vol. 42, no. 3, pp. 175-178, 2012.

[3] P. Nishiyama, "Low Enriched Uranium Ual X -Al Targets for the Production of Molybdenum-99 in the IAER1 and RMB Reactors," 2011.

[4] P. H. Liem, H. N. Tran, and T. M. Sembiring, "Design optimization of a new homogeneous reactor for medical radioisotope Mo-99/Tc-99m production," Prog. Nucl. Energy, vol. 82, pp. 191-196, 2015.

[5] S. Pinem, S. Jati, Tukiran, and T. Sembiring, "Optimization of Radioisotope Production at RSG-GAS Reactor Using Deterministic Method," Teknologi Indonesia, vol. 35, no. January 2012, pp. 37-45, 2016.

[6] Sutrisno, "Analisis Optimasi Target 235 U Pengkayaan Rendah (LEU) Untuk Mendukung Produksi 99 Mo Dan Target Batu Topaz di Reaktor RSG-GAS," Ganendra, J. Iptek Nukl., vol. 21 No.1, pp. 25-35, 2018.

[7] M. Marlina, S. Sriyono, E. Lestari, A. Abidin, H. Setiawan, and K. Kadarisman, "Desain dan Performa Prototipe Generator 99Mo/99mTc dengan Kolom Material Berbasis Zirkonium dan Kolom Alumina," J. Kim. dan Kemasan, vol. 38, no. 2, p. 93, 2016.

[8] S. K. Lee, G. J. Beyer, and J. S. Lee, "Development of Industrial-Scale Fission 99Mo Production Process Using Low Enriched Uranium Target," Nucl. Eng. Technol., vol. 48, no. 3, pp. 613-623, 2016.

[9] IAEA, "IAEA Nuclear Energy Series Non-HEU Production Technologies for Molybdenum-99 and," IAEA Nucl. Energy Ser., pp. 1-75, 2013.

[10] IAEA, "Feasibility of Producing Molybdenum-99 on a Small Scale Using Fission of Low Enriched Uranium or Neutron Activation of Natural Molybdenum," Tech. Reports Ser. No.478, no. 478, 2015.

[11] P. H. Liem, "Validation of BATAN'S Standard 3-D Diffusion Code, BATAN-3DIFF, on the First Core of RSG GAS," Atom Indones., vol. 25, no. 1, pp. 47-53, 1999.

[12] A. Mohammad, T. Mahmood, and M. Iqbal, "Fission MOLY production at PARR-1 using LEU plate type target," Nucl. Eng. Des., vol. 239, no. 3, pp. 521-525, 2009.

[13] J. Medel and G. Torres, "Neutronic analysis for the fission Mo-99 production by irradiation of a LEU target at $\mathrm{RECH}-1$ reactor," pp. 1-9.

[14] WIMSD5, "Deterministic Multigroup Reactor Lattice Calculations, NEA-1507/04." 2004.

[15] S. Pinem, L. Suparlina, and T. Surbakti, "Effect Of U-9Mo/Al Fuel Densities on Neutronic And Steady State Thermal Hydraulic Parameters of MTR Type Research Reactor," in KnE Energy, 2016, vol. 1, no. 1, pp. 1-9.

[16] D. Jo, K. H. Lee, H. C. Kim, and H. Chae, "Neutronic and thermal hydraulic analyses of LEU targets irradiated in a research reactor for Molybdenum-99 production," Ann. Nucl. Energy, vol. 71, pp. 467-474, 2014.

[17] BATAN, "Multipurpose Reactor G.A. Siwabessy Safety Analysis Report. Rev. 8. Indonesia, 1999." 